\title{
STAND-ALONE PHOTOVOLTAIC AND HYDROGEN PLANT COUPLED WITH A GAS HEAT PUMP FOR GREENHOUSE HEATING
}

\author{
Alexandros Sotirios ANIFANTIS, Francesco SANTORO, Simone PASCUZZI, \\ Giacomo SCARASCIA MUGNOZZA \\ Department of Agricultural and Environmental Science (DiSAAT), University of Bari Aldo Moro, ITALY \\ Email of corresponding author: alexandrossotirios.anifantis@uniba.it
}

Keywords: Ground source gas heat pump, photovoltaic-hydrogen plant, Greenhouse heating.

\begin{abstract}
In recent years, the increasing interest in energy production from renewable energy sources has led to standalone renewable energy plant being developed in agricultural land. In particular, for greenhouses heating, diesel, LPG and natural gas are the main energy sources used. Alternative solutions are represented by the integration of renewable energy plants in off grid configurations. The aims of this research is to analyzed the energy performance of a photovoltaic, hydrogen and ground source gas heat pump integrated standalone system during the winter season. The results showed that the system had a total energy efficiency to $13 \%$. The performance of the system was low because the efficiency of the photovoltaic panels was the bottleneck. In fact, starting from the energy available from the PV, the system has an efficiency of $96 \%$ if the COP of the heat pump is equal to 4 . Finally, the heating system increased the greenhouse air temperature about $8^{\circ} \mathrm{C}$ respect to the external air temperature.
\end{abstract}

\section{INTRODUCTION}

Nowadays, several research attempts are focus on the micro-generation systems based on renewable energy sources in according with the Near Zero Energy Building (NZEB) concept and the new European Directive 2010/31/CE. However, in agricultural sector, in case biomasses are not available, some attractive solutions are represented by the geothermal heating systems (Anifantis et al., 2016) and stand-alone hydrogen plant (Anifantis et al., 2017). Transforming the solar radiation surplus into electrical energy is of extreme interest due to its double benefit: it solves the problem of excess solar radiation in the greenhouse and produces electricity from renewable sources without negative environmental effects (Marucci et al., 2017). Unfortunately, the energy production and consumption of solar energy for greenhouse requests are non-simultaneity and the electric energy produced during the daylight hours must be stored and reuse in the night. Then, the surplus electricity from wind farms or solar PV farms if not used can be stored using batteries. However, the uncertainties in the cost of batteries are rather wide, even larger than difference in costs between different technologies (Zakeri \& Syri, 2015). Alternatively, the electricity can be stored in the form of hydrogen gas, the surplus electricity is used for water electrolysis to generate hydrogen gas that can stored and when electricity is needed, then this hydrogen gas can be used as feedstock for the PEM fuel cells to produce electricity or can be burned in internal combustion engines (ICE) to generate mechanical or electrical energy. Other interesting technologies for energy storage are hydropower generation, flywheels and compressed air energy storage (CAES) (Ghoniem, 2011). In this paper, a photovoltaic and hydrogen stand-alone systems integrated with a ground source gas heat pump (GSGHP) for greenhouse heating was studied. The GSGHP is composed by an internal combustion engine drive shaft connected to a compressor of a geothermal heat pump. The engine was feed by the hydrogen produced by an PEM electrolyzer during the daylight hours. A performance analysis was conducted in order to define the total efficiency and the power production of the integrated system. 


\section{MATERIALS AND METHODS}

The only behavior of the gas heat pump was mathematical modeled using the technical manuals provided by the manufacturer AISIN (TOYOTA group). Instead the rest of the system components have been analyzed using the data of an hydrogen plant implemented at the experimental farm of the University of Bari, located in Valenzano, Italy. In particularly, the electricity generated by $56 \mathrm{~m}^{2}$ (APV) of polycrystalline photovoltaic panels (PV), during day time from 08:30 to 17:30, fed a electrolyzer which produces hydrogen by water electrolysis. The hydrogen was stored in a pressure tank at 30 bar. The ground source gas heat pump heated an air-inflated, double layer polyethylene film tunnel greenhouse of $106 \mathrm{~m}^{2}$ of cover surface $\left(\mathrm{A}_{\mathrm{cf}}\right)$ and $48 \mathrm{~m}^{2}$ of area. The diagram of the plant is shown in Fig. 1 and the specifications of the plants are reported in Tab. 1. The experimental test was carried out in a winter day of February.

Table 1. Specifications of two renewable energy hydrogen plant.

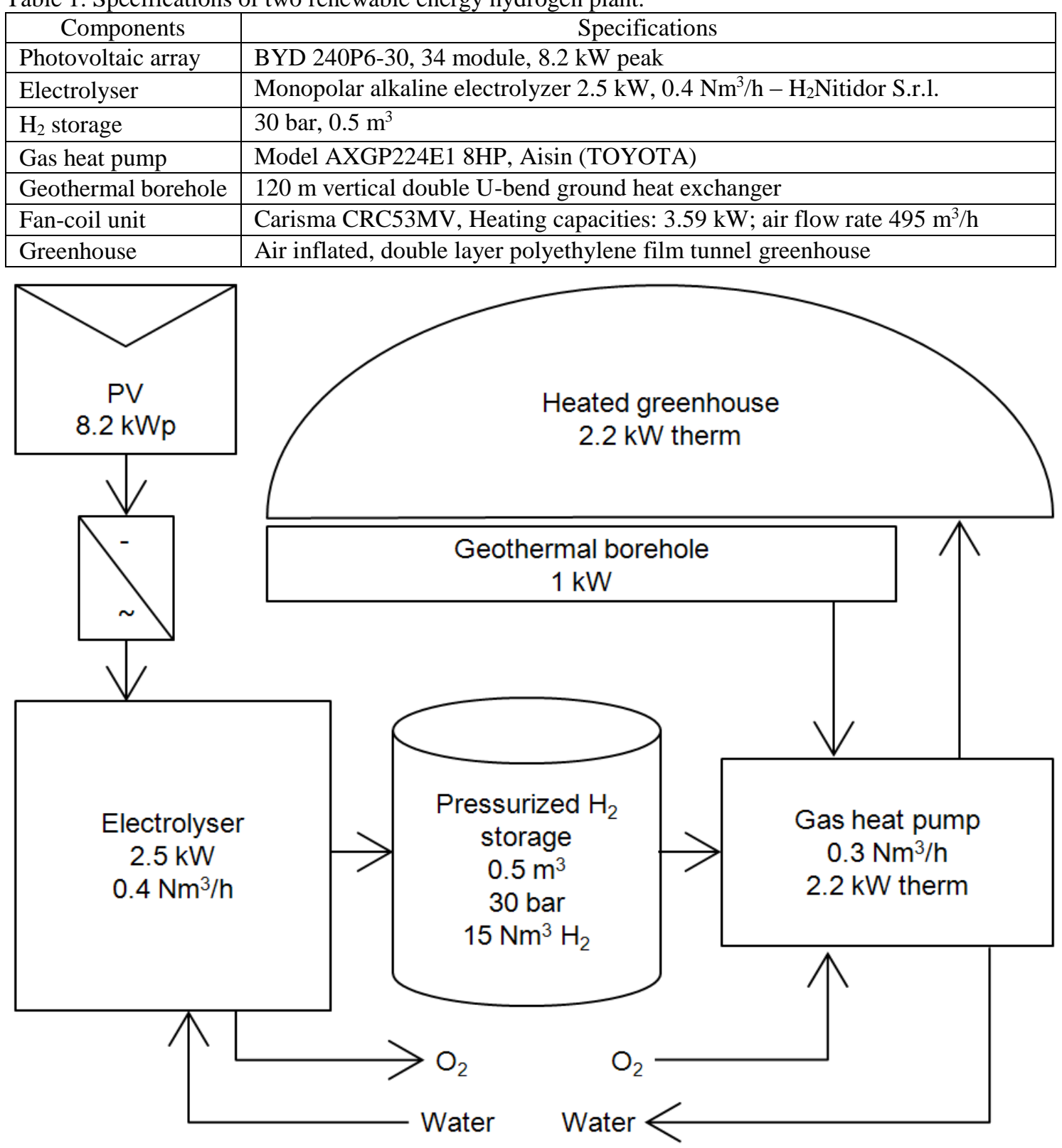

Figure 1. PV and GSGHP in a stand-alone hydrogen system for greenhouse heating. 
Considering a clear day, the fraction of the instantaneous PV array power output used through electrolyzer input $\left(\mathrm{P}_{\mathrm{el}}\right)$ is given by (Anifantis et al., 2017):

$$
P_{\mathrm{el}}=\Phi \eta_{\mathrm{vr}} \mathrm{A}_{\mathrm{PV}} \mathrm{I}_{\mathrm{T}} \eta_{\mathrm{r}}\left[1-B\left(T_{c}-T_{\mathrm{r}}\right)\right]
$$

where $\eta_{\mathrm{r}}(=0.15)$ is the efficiency of the solar cell at a referenced solar radiation, $\mathrm{T}_{\mathrm{c}}\left(\sim 35^{\circ} \mathrm{C}\right)$ the solar cell temperature, $\mathrm{T}_{\mathrm{r}}\left(=25^{\circ} \mathrm{C}\right)$ the referenced temperature of the cell and $\mathrm{B}\left(=0.005^{\circ} \mathrm{C}^{-1}\right)$ the temperature coefficient of a solar cell, APV the PV array surface, $\mathrm{I}_{\mathrm{T}}$ the solar radiation, $\eta_{\mathrm{vr}}(=0.97)$ the DC/AC converter efficiency and $\Phi$ the solar radiation usability. $\Phi$ was necessary because the peak power of the PV array should be increased to assure enough available power to cover the needs of the electrolyzer.

Instead, the energy efficiency of the electrolysis reaction $\eta_{\mathrm{el}}$ is given in terms of the lower heating value of hydrogen $\left(\mathrm{LHV}_{\mathrm{H} 2}=119.96\left[\mathrm{MJ} \mathrm{kg}^{-1}\right]\right)$, the overall hydrogen production rate $\mathrm{q}_{\mathrm{el}, \mathrm{H} 2}\left[=0.00011 \mathrm{Nm}^{3} \mathrm{~s}^{-1}\right]$ and the hydrogen density at standard condition $\left(\delta_{\mathrm{H} 2}=0.09\left[\mathrm{~kg} \mathrm{Nm}^{-3}\right]\right)$ by the expression (Calderóna et al, 2011):

$$
\eta_{e l}=\frac{\delta_{H_{2}} \cdot q_{e l, H_{2}} \cdot L H V_{H_{2}}}{P_{e l}}
$$

Gas driven heat pumps performance was calculated by using the Gas Utilization Efficiency (GUE) given by the manufacturer (TecnoCasa Climatizzazione Sole European Distributor AISIN, 2017):

$$
\begin{aligned}
& \text { GUE }=0.64+0.32 \cdot \mathrm{COP} \\
& \mathrm{Q}_{1}=\mathrm{GUE} \cdot \mathrm{Q}_{1 \_ \text {burner }}
\end{aligned}
$$

where, considering the overall hydrogen consumption rate of the GSGHP qGSGHP,H2, the equivalent thermal power supplies by an ideal hydrogen burner $\mathrm{Q}_{1 \_ \text {burner }}$ is given by:

$$
Q_{1 \_ \text {burner }}=\delta_{H_{2}} \cdot q_{G S G H P, H_{2}} \cdot L H N_{H_{2}}
$$

Thanks to the $\mathrm{Q}_{1 \_ \text {burner }}$ is possible to calculate the thermal power supplies by the heat pump to the thermal hating system inside the greenhouse $\left(\mathrm{Q}_{1}\right)$ that is equal to the thermal power demand of the greenhouse.

The ground source gas heat pump (GSGHP) has the same coefficient of performance (COP) of a common ground source heat pump (GSHP):

$$
\mathrm{COP}=\frac{\mathrm{Q}_{1}}{\mathrm{Q}_{1}-\mathrm{Q}_{2}}
$$

where $\mathrm{Q}_{2}$ is the heat power extracted from the ground through the borehole-probe heat exchanger. $\mathrm{Q}_{2}$ is given by:

$$
\mathrm{Q}_{2}=q_{\mathrm{r}} \cdot \mathrm{I}_{\mathrm{t}}
$$

where $\mathrm{q}_{\mathrm{r}}$ is the heat exchange rate and $\mathrm{l}_{\mathrm{t}}$ is the total active length of the borehole. Considering the steady state and the overnight winter conditions, the thermal power demand of the greenhouse was assessed with the equation (Ozgener \& Hepbasli, 2005):

$$
Q_{1}=\left[\frac{\mathrm{A}_{\mathrm{cf}}}{\mathrm{R}}\right]\left(f_{\mathrm{w}}\right)\left(f_{c}\right)\left(f_{s}\right)\left(T_{i}-T_{a}\right)
$$

Assuming 1, 0.9 and 1 for the wind factor $\left(f_{w}\right)$, construction type factor $\left(f_{c}\right)$ and system factor $\left(\mathrm{f}_{\mathrm{s}}\right)$, respectively and $0.28 \mathrm{~m}^{2}{ }^{\circ} \mathrm{C} / \mathrm{W}$ for the greenhouse thermal resistance $(\mathrm{R})$. 


\section{RESULTS AND DISCUSSION}

The results show that the use of a ground source gas heat pump unit integrated with a photovoltaic stand-alone hydrogen system allows to have a total energy efficiency of $13 \%$, starting from the sun to the GSGHP. The major limitation to the performance of the whole system was represented by the performance of photovoltaic, in fact, starting from the energy available from the PV, the system has a $96 \%$ efficiency with a heat pump COP of 4 . The heating system increasing the greenhouse temperature by about $8^{\circ} \mathrm{C}$ compared with the ambient conditions in a representative winter day of February.

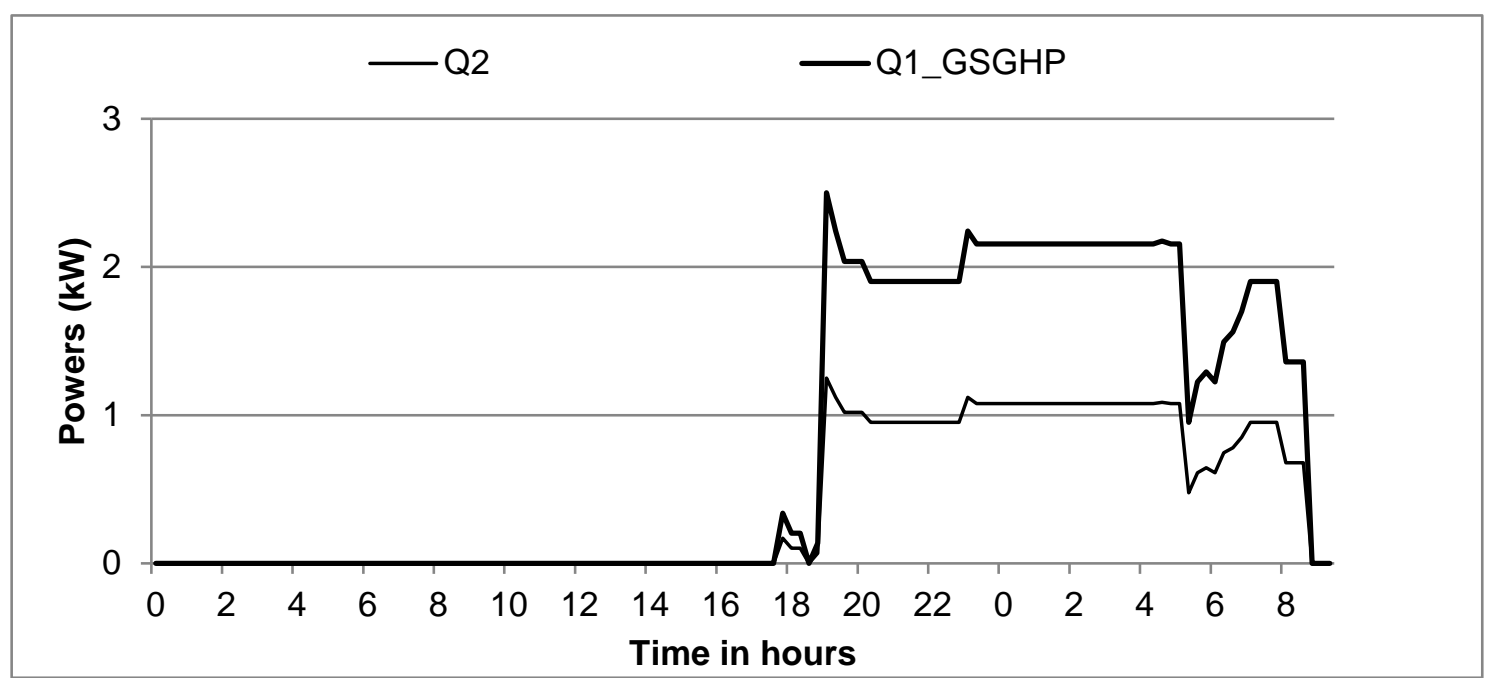

Figure 2. Equivalent thermal power supplies by the hydrogen burner (Q1_burner) and heat power extracted from the ground $(\mathrm{Q} 2)$ during a winter day.

At night, the fuel cell and the GSHP worked from 18:30 to 08:30 and start when the temperature decreased to $10^{\circ} \mathrm{C}$. The thermal power output $\left(\mathrm{Q}_{1}\right)$ and input $\left(\mathrm{Q}_{2}\right)$ of the GSGHP is $2 \mathrm{~kW}$ and $1 \mathrm{~kW}$ respectively (Fig. 2). The heat exchange rate of the geothermal borehole required $\left(\mathrm{q}_{\mathrm{r}}\right)$ for a double $\mathrm{U}$-bend pipe is $10 \mathrm{~W} \mathrm{~m}^{-1}$. The difference between the indoor and outdoor greenhouse temperatures ( $\left.\mathrm{T}_{\mathrm{i} \text { GSGHP}}-\mathrm{T}_{\mathrm{a}}\right)$ was $8^{\circ} \mathrm{C}$ (Fig. 3).

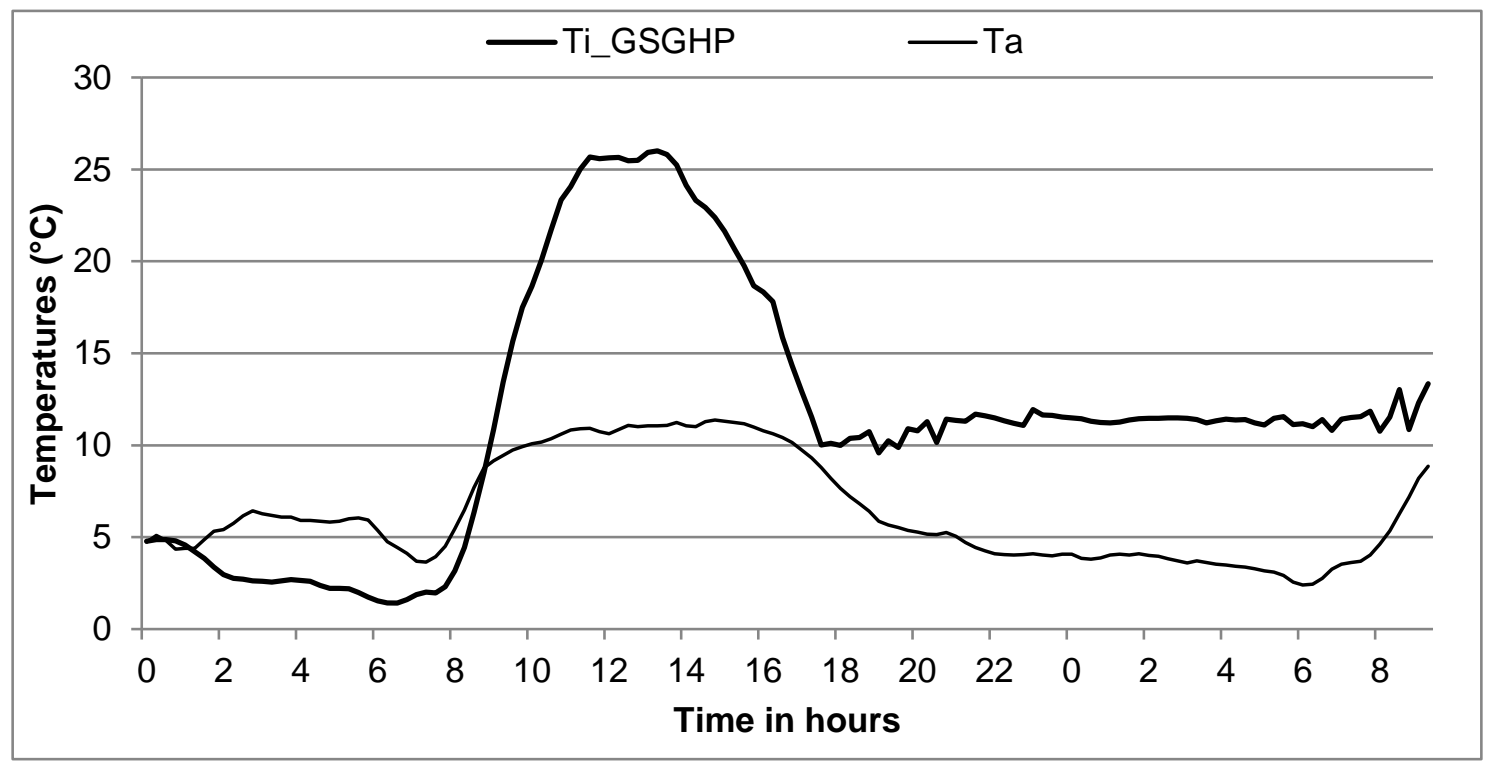

Figure 3. Internal and external greenhouse air temperature during a winter day. 


\section{CONCLUSION}

The present paper analyzed the overall performance efficiency of a ground source gas heat pump integrated with a stand-alone renewable energy plant. The results obtained in these trials and the mathematical model implemented allow some remarks about the performance and efficiency of the water electrolyzer and the geothermal source gas hat pump (Aisin-TOYOTA). These trials give us a glimpse to its usage within a greenhouseintegrated heating system comprised of photovoltaic panels, alkaline barometric water electrolyzer, hydrogen storage and geothermal source gas heat pump even if experimental tests are required to better assess the GSGHP's achievement. The electrolyzer worked non-stop during the days characterized by clear skies but the electrical power supplied by the PV modules was greatly affected by the very unstable solar radiation during the partial cloudy day. In these cases, the electrolyzer overall operation was disjointed sometimes for many hours due to intemperate weather conditions in which the hydrogen production was cut off. The energy efficiency of the plant is strongly affected by electrolyzer and gas heat pump management. Considering the energy efficiency of photovoltaic panels of $13 \%$, an electrolyzer energy efficiency equal to $50 \%$, a ground source gas heat pump GUE of $192 \%$ respectively, the overall system efficiency is $13 \%$. Finally, the heating system increasing the greenhouse temperature by about $8^{\circ} \mathrm{C}$ compared with the ambient conditions in a representative winter day of February.

\section{ACKNOWLEDGMENTS}

Funding source: Fondo di Sviluppo e Coesione 2007-2013 - APQ Ricerca Regione Puglia "Programma reg. a sostegno della specializzazione intelligente e della sostenibilità sociale ed ambientaleFutureInResearch".

\section{REFERENCES}

Anifantis, A. S., Colantoni, A., \& Pascuzzi, S. (2017). Thermal energy assessment of a small scale photovoltaic, hydrogen and geothermal stand-alone system for greenhouse heating. Renewable Energy, 103, 115-127. doi:10.1016/j.renene.2016.11.031

Anifantis, A. S., Pascuzzi, S., \& Scarascia-Mugnozza, G. (2016). Geothermal source heat pump performance for a greenhouse heating system: An experimental study. Journal of Agricultural Engineering, 47(3), 164-170. doi:10.4081/jae.2016.544

Calderóna M., Calderóna A.J., Ramirob A., Gonzálezb J.F. \& Gonzáleza I. (2011). Evaluation of a hybrid photovoltaic-wind system with hydrogen storage performance using exergy analysis. International Journal of Hydrogen Energy, 36, 5751-5762. doi:10.1016/j.ijhydene.2011.02.055

Ghoniem, A. F. (2011). Needs, resources and climate change: Clean and efficient conversion technologies. Progress in Energy and Combustion Science, 37(1), 15-51. doi:10.1016/j.pecs.2010.02.006

Ozgener O. \& Hepbasli A. (2005). Performance analysis of a solar ground-source heat pump system for greenhouse heating: an experimental study. Building and Environment, 40, 1040-1050. doi:10.1016/j.buildenv.2004.08.030

Marucci A., Monarca D., Colantoni A., Campiglia E. \& Cappuccini A. (2017). Analysis of the internal shading in a photovoltaic greenhouse tunnel. Journal of Agricultural Engineering; 47(622), 154-160. doi:10.4081/jae.2017.622

TecnoCasa Climatizzazione Sole European Distributor AISIN, Gas Heat Pump (GHP) / Microcogenerator (MCHP). Available online: URL www.tecno-casa.com (accessed on 15 September 2017).

Zakeri, B., \& Syri, S. (2015). Electrical energy storage systems: A comparative life cycle cost analysis. Renewable and Sustainable Energy Reviews, 42, 569-596. doi:10.1016/j.rser.2014.10.011 